\title{
Legal Limits of AIDS Confidentiality
}

\author{
Bernard Dickens
}

Version Publisher's Version

Citation Bernard Dickens, "Legal Limits of AIDS Confidentiality" (1988) 259

(published version) Journal of the American Medical Association 3449.

Copyright / License Reprinted with permission from the American Medical Association. This article has been published in final form at:

https://jamanetwork.com/journals/jama/fullarticle/372426

How to cite TSpace items

Always cite the published version, so the author(s) will receive recognition through services that track citation counts, e.g. Scopus. If you need to cite the page number of the author manuscript from TSpace because you cannot access the published version, then cite the TSpace version in addition to the published version using the permanent URI (handle) found on the record page.

This article was made openly accessible by $U$ of ' $T$ Faculty. Please tell us how this access benefits you. Your story matters. 


\section{Legal Limits of AIDS Confidentiality}

\author{
Bernard M. Dickens, PhD, LLD
}

THE IMPACT that the acquired immunodeficiency syndrome (AIDS) is having on social relationships finds expression in legal relationships. The medical or health care setting is only one of many in which legal rights, duties, and powers are affected by individuals' liability to transmit or to suffer from human immunodeficiency virus (HIV) infection. ${ }^{1}$ Medical diagnosis, care, and counseling of patients with AIDS certainly raise crucial concerns of health care professionals, allied health workers, and patients. Their concerns are, however, representative rather than exhaustive of those felt throughout society.

Fears of HIV infection contracted in the workplace are unreasonable, but nevertheless commonplace, in all but a few occupations. Where fellow employees risk wounds that bleed, for instance, colleagues may demand protection. In schools, teaching and auxiliary staff may fear exposure to children's body fluids, more frequently passed, no doubt, by younger children, and the same is true in day-care centers. Proximately shared housing may cause occupants to fear their neighbors infection, and partners in recreational activities, particularly body-contact sports that involve the shedding of perspiration and blood, may have additional grounds for unease. In commerce, insurance companies have publicized their apprehensions of unknowingly writing life or health insurance policies for AIDS sufferers, which may upset their balance of expenditures and premium income.

Health care professionals, employers, fellow employees, educators, and neighbors may claim legitimate interests of self-protection in knowing who is liable to transmit HIV. They may demand disclosure of the identities of persons with AIDS, AIDS-related complex (ARC), or positive test results for exposure to HIV. Hospital and public health officers then come under pressure to serve these individuals' asserted rights to know, even at the cost of compromising their patients right to confidentiality.

The response from professionals has varied. Some critics point out that disclosure of HIV-antibody test results would be dysfunctional if it caused those whose blood tested negative to be presumed not infected, since the test may have been conducted during incubation of the AIDS virus. Hence, everyone must initially be presumed infected irrespective of testing and test results. Others, particularly in the public health field, contend that liability to disclosure of identity would deter from submission to testing members of high-risk populations who represent the greatest risk of spreading HIV infection. Almost all critics point to laws, however, that mandate the maintenance of strict confidentiality of medical data. Legislation, often detailed in subordinate regulations and enforced in litigated cases, shows the law's determination to reinforce ethical duties of maintaining confidentiality of medical information by legal sanctions, both penal and compensatory.

It will be argued herein, however, that, in the context of

From the Faculty of Law and Faculty of Medicine, University of Toronto. Dr Dickens was a Julius Silver Fellow, Columbia University Law School, New York

Reprint requests to Faculty of Law, University of Toronto, Toronto, Ontario, Canada M5S 2C5 (Dr Dickens).
HIV infection, the law's protection of medical confidence is frequently illusory. It will be shown that while some laws appear to require and provide secrecy of medical data, others compel disclosures; moreover, justifications and excuses of breaches of confidentiality exist under transcending legal doctrines. It is concluded that the most effective use of legislation is not simply to seek to enact further protections of confidentiality of data, which would be subject to the same exceptions, but to reinforce laws against discrimination on grounds of an individual's affliction with AIDS, ARC, or HIV infection.

\section{THE DUTY TO WARN}

Liability to transmit HIV infection represents a danger to health and to life itself. The law has priorized preservation of medical confidentiality and preservation of human life, not in the context of AIDS but in a patient's anticipated potential to endanger another person's life. In the widely discussed Califormia Supreme Court case of Tarasoff $v$ Regents of the University of California, ${ }^{2}$ the defendants argued, inter alia, that a legal duty of confidentiality prevented a warning from being given to a person (or to his or her family) who was predicted to be at risk from possible attack from a mental health patient. Legislation often permits psychiatrists, psychologists, and comparable mental health professionals to enjoy the privilege to preserve patients' confidences, because disclosure would jeopardize therapeutic relationships that are in the public interest to foster. The defendant invoked both law and policy to support silence in the face of diagnosed danger to an identifiable victim. The Court observed that: "We recognize the public interest in supporting effective treatment of mental illness and in protecting the rights of patients to privacy, and the consequent public importance of safeguarding the confidential character of psychotherapeutic communication. Against this interest, however, we must weigh the public interest in safety from violent assault."8

In priorizing confidentiality and safety, the Court concluded that "the public policy favoring protection of the confidential character of patient-psychotherapist communications must yield to the extent to which disclosure is essential to avert danger to others. The protective privilege ends where the public peril begins."

The Tarasoff principle, though initially contentious, has spread beyond California and beyond a duty to act in cases where the victim of another's foreseeable dangerousness is known, to those instances in which the victim is not individually identifiable. ${ }^{5}$ The principle appears no less applicable to danger by spreading HIV infection than to danger by violence.

Dangerousness is a legal status rather than a psychiatric disposition or a condition of infectiousness. ${ }^{6}$ Physicians and related professionals are recognized to have special legal relationships, of a tortious and fiduciary nature, toward third parties they anticipate or reasonably should anticipate being harmed by their patients. Particularly if victims are identifiable, they are owed a duty to be warned. If they are individually unidentifiable, warning to others, such as the police, may be legally required. If legislation mandates preservation of patients' confidentiality, it would probably be read as subject to this limitation, unless the enactment provides otherwise by explicit terms. It is of no consequence that the goal of the mandated protection of confidentiality, namely, to encourage recourse to professional care in the public interest, is thereby compromised.

Accordingly, where general legislation appears to offer 
HIV-infected patients protection against disclosure of their condition, it may not prevail over a contending claim that known potential victims of that transmissible infection, such as spouses, are entitled to receive information of the source and nature of the risk to their health and lives. If potential victims are unidentifiable, disclosure of infected persons' names to public health authorities would be justified where not expressly mandated by law, and the police powers of states would be applicable, notably to detain under quarantine provisions. ${ }^{3}$

\section{THE POWER TO WARN}

When legislation has created no duty to give information about an HIV-infected person's identity or threat of danger and when tort law and fiduciary responsibilities similarly provide no duty to warn, the law may nevertheless recognize a power to warn that is exercisable in good faith. It has been considered justifiable, for instance, to violate medical confidentiality to give warning of a patient's propensity to bring distress to an intended marriage partner.

In Berry $v$ Moench, ${ }^{8}$ the physician was a psychiatrist who disclosed his patient's diagnosis to inform the parents of the patient's fiancee. The patient sued for libel, and the psychiatrist pleaded alternative defenses of truth and conditional privilege. Defamation law concerns communication of injurious falsehood, whereas breach of confidentiality concerns improper communication of truths. The court addressed whether liability would follow were the physician's revelations untrue and concluded that it would not, provided that the physician was neither malicious nor careless. It was observed that "...the responsibility of the doctor to keep confidence may be outweighed by a higher duty to give out information, even though defamatory, if there was [sic] a sufficiently important interest to protect.... Where life, safety, well-being or other important interest is in jeopardy, one having information which could protect against the hazard, may have a conditional privilege to reveal information for such purpose, even though it may be defamatory and prove to be false." $"$

This approach seems applicable to disclosure of HIV positivity and covers conscientious disclosure of a test outcome even when it proves to be a false-positive result. More restrictively, however, the Court observed that disclosure of even truthful information may not be permissible in defamation law if it is excessive. The following criteria were established to determine whether the privilege of disclosure exists: (1) the physician must use good faith and reasonable care to tell the truth; (2) the information must be reported fairly; (3) only necessary information must be given; and (4) publication must be limited to those persons necessary for protection of the threatened interest. ${ }^{10}$

Legislation mandating preservation of confidentiality of persons who are HIV positive may accordingly be subject to an implied exception allowing a limited power of disclosure when necessary to protect "life, safety, well-being or other important interest." This recognition of necessity in civil law mirrors criminal law's accommodation of the necessity defense.

\section{CRIMINAL LAW}

Criminal law has a long tradition of tolerating violations of legal prohibitions, provided that they were inspired by the motive to save human life. Indeed, provided that proper procedures of decision making have been applied, the courts may accept the defense of necessity to save human life, of a person in particular or of persons in general, for even the egregious crime of willfully causing death itself. ${ }^{21}$ On this scale of values, it is evident that willful violation of laws mandating protection of medical confidentiality committed to reduce individual risk of exposure to HIV infection can be legally defensible. The rate of progression to AIDS of those who are infected with HIV is not established, but for purposes of law, a claimed motive to protect against HIV exposure, to save life, may seem credible.

Consistent with the criminal law principle that defendants are judged according to the facts as they see them, including mistaken facts, the initial question is whether the proven violator of confidentiality sincerely perceived a lethal menace. This is a subjective question resolved by a subjective finding, but a defendant's assertion of fact is reinforced where the claimed perception is objectively reasonable. ${ }^{12}$ Determination of a lethal menace from transmission of HIV may seem reasonable, either by virtue of scientific data about the spread of the infection or by the strength of popular belief.

The second question is whether, accepting the facts as perceived, the defendant's priorization of values, setting the interest sought to be protected (saving human life) against the value willfully sacrificed (confidentiality), is objectively proportionate. Courts themselves have been willing to subordinate medical confidentiality to protect potential victims lives and health. Courts also require, however, that the means chosen be the minimum necessary under the circumstances.

This objective priorization and the principle of proportionality are challenged by legislation enacted expressly for the purpose of protecting from disclosure medical evidence of HIV infection. The political process resulting in such legislation offers a clear statement of prevailing social values. Courts may nevertheless find that a defendant's sense of necessity to save life invokes pervasive values that the legislation does not intend to displace because they concern not just the transitory preference of public health policy but also the enduring sentiments of the people concerning the sanctity of life. Accordingly, AIDS legislation reinforcing confidentiality may have difficulty in excluding charged defendants' reliance on the defense of necessity to breach confidentiality.

Criminal process provides further exceptions to legislation limiting identification of HIV-infected persons. Some who have risked transmission of the virus to others, for instance, through unprotected sexual intercourse, have been charged with commission of offenses. Attempted murder charges have been considered. ${ }^{18}$ For instance, in South Carolina an infected detainee who bit his captor was charged with assault with a deadly weapon (New York Times, June 25,1987 ), while in Los Angeles a man was charged with attempted murder for knowingly selling his HIV-infected blood for transfusion (New York Times, June 30, 1987).

Whatever the outcome of such cases, they are part of criminal process and, except in the case of juveniles, they attract news media coverage that names the defendants (as happened in the South Carolina and Los Angeles cases). Constitutional protections of freedom of the press justify or at least excuse publication of names and specific medical histories of HIV-diagnosed persons arrested for and charged with committing offenses. This marks a further limit of confidentiality laws.

\section{POLICE POWERS}

In the Tarasoff case, ${ }^{2}$ the patient's identity and anticipated pathologic behavior were communicated to campus police. Although the defendants made a spirited claim that they were mandated to protect medical confidentiality despite considerable danger to an identifiable prospective victim, they never considered that disclosure to the police was improper. The police are commonly presumed to be within the charmed circle of those entitled to be informed of anticipated injuries that medical patients, due to their conditions, may cause others.

Public health authorities share with mental health authorities $^{14}$ a function to discharge the state's policing responsibility for public protection against dangerous persons and may lawfully be given information appropriate for the discharge of 
that function. Furthermore, legislation often mandates that, notwithstanding confidentiality duties owed by others, information be given to these authorities. Cases of AIDS, as defined by the Centers for Disease Control, Atlanta, are compulsorily reportable in every state, and a number of states require reporting of positive HIV-antibody test results. In addition, general provisions that do not specify HIV infection as notifiable require reporting of incidents related to listed diseases, including AIDS. ${ }^{15}$

Constitutionally protected rights of privacy generally limit information that policing agencies can demand, but these rights may be inapplicable to homosexual conduct.$^{16}$ General legal requirements to report AIDS or HIV infection would appear constitutional under the US Supreme Court's doctrine stated in Whalen $v R o e^{17}$ if (1) the information were reasonably related to a valid public health purpose; (2) the information were limited to public health departments; and (3) there were adequate statutory confidentiality protections in place.

Like other state policing services, public health agencies are inclined to protect their informants identities from disclosure, but those to whom they legitimately release information may be under no reciprocal legal or enforceable duty of confidentiality.

The US Supreme Court's acceptance in Whalen $v$ Roe of governmental maintenance of personally identifiable records of confidential medical information-provided that adequate protections exist against improper disclosures - was given soon after the Tarasoff decision in California. The Supreme Court acknowledged that public disclosure of patient information could occur in a number of deliberate and negligent ways. The Court was persuaded, however, that the legislated program of data storage in question did not, on its face, pose a sufficiently grievous threat to patients' interests in nondisclosure of private information and in making important health care decisions without state intervention to establish a constitutional violation. Public health considerations were thereby balanced favorably against concerns to protect the highest possible level of personal confidentiality.

Commentators and critics have pointed to the failure of historic public health statutes currently in force to reflect modern conceptions in science and law and to the extent to which complacency about the exercise of compulsory powers has been displaced by the AIDS epidemic. ${ }^{18}$ Agencies themselves may be adequately vigilant about confidentiality of data compulsorily submitted, but when sexual contact tracing is undertaken, information may pass to persons not necessarily bound by the same standards. Thus, information can seep into general circulation and be beyond protection. When the physician and manager of the late entertainer Liberace preserved confidentiality of the cause of death, members of the news media voiced their suspicions of deceit and forced a public officer's disclosure of the medical facts, notwithstanding California's legislation of provisions for confidentiality.

\section{CONCLUSION}

Reliance cannot be placed on the law to restrict breaches of confidentiality of HIV-infected persons' identities. Too much in the law itself compels, justifies, and excuses disclosure of information. Victims of the disease exposed to stigmatization, humiliation, ostracism, and even physical assault of their persons and homes cannot confidently seek legal remedies for harmful disclosures when the law requires or tolerates publicity of their medical condition. Legislative planning is better devoted not simply to enacting further confidentiality provisions but also to minimizing discrimination against infected persons in such areas as employment, housing, education, insurance, and access to medical care once their condition becomes known. ${ }^{19}$

Legislation proposed by Senator Kennedy and Representative Waxman to amend the Public Health Service Act to protect persons with AIDS or related conditions points in the right direction. Applicants for grants to support counseling and testing programs regarding HIV infection must agree to comply with federal, state, and local laws aimed to ensure confidentiality of information and records of those counseled or tested. To the extent permitted by relevant law, opportunities should be offered for anonymous counseling and testing. Unjustified breaches of confidentiality attract civil monetary penalties, civil claims for damages or other remedies, and criminal penalties. Emphasis is given, however, to the prohibition of discrimination against those who are, or who are regarded as being, infected with HIV in employment, housing, public accommodations, and governmental services. Discrimination is similarly prohibited in the provision of benefits under any program or activity that receives or benefits from federal financial assistance. Discrimination attracts liability to civil monetary penalties and civil causes of action, including prohibitory injunction. The coupling of confidentiality protections to provision against discrimination acknowledges that reliance cannot be placed on confidentiality provisions alone.

Patients with AIDS exist preponderantly among populations of homosexual men, drug users, and prostitutes who already face considerable discrimination. Their activities are frequently criminal, and specialized police forces such as morality and antidrug squads focus on reducing and frustrating pursuit of these practices. Aware of their liability to suffer discrimination, members of these populations will not seek testing or help from public agencies unless reassured that they will not be further isolated by hostile responses and loss of liberties.

The US Supreme Court's finding that a person with tuberculosis is handicapped within the meaning of the federal Rehabilitation $\mathrm{Act}^{20}$ provides grounds to believe that persons with AIDS, ARC, and HIV positivity are similarly handicapped. They are accordingly protected against discrimination in federally funded programs. Achievement of public health goals of containing the spread of HIV infection, by reaching highrisk populations and affording them education and means to protect themselves and others, will not be advanced simply by enacting promises of confidentiality. These promises are too liable to prove flawed and illusory, because of doctrines and dispositions of the law itself. More is likely to be gained by enacting and enforcing protections against discrimination in crucial areas for those affected persons whose identities are likely to become known.

\section{References.}

1. Dickens BM: Legal rights and duties in the AIDS epidemic. Science 1988;239:580-586.

2. Tarasoff $v$ Regents of the University of California, $551 \mathrm{P} 2 \mathrm{~d} 334$ (Cal 1976).

3. Tarasoff $v$ Regents of the University of California, $551 \mathrm{P2d} 346$ (Cal 1976).

4. Tarasoff $v$ Regents of the University of California, 551 P2d 347 (Cal 1976).

5. Peterson $v$ the State, 671 P2d 230 (Wash 1983).

6. The State $v$ Hudson, 409 A2d 1349 (NH 1979).

7. Parmet WE: AIDS and quarantine: The revival of an archaic doctrine. Hofstra Law Rev 1985;14:53-90.

8. Berry $v$ Moench, 331 P2d 814 (Utah 1958).

9. Berry v Moench, $331 \mathrm{P2d} 817-818$ (Utah 1958).

10. Berry $v$ Moench, $331 \mathrm{P} 2 \mathrm{~d} 819$ (Utah 1958).

11. US v Holmes, 26 Fed Cas 360 (Cir ED Penn 1842).

12. Lambek BD: Necessity and international law: Arguments for the legality of civil disobedience. Yale Law Policy Rev 1987;5:472-492.

13. HIV-positive man charged with intent to kill. AIDS Policy Law 1987;2:6.

14. Rogers $v$ Commissioner of Mental Health sub nom Rogers $v$ Okin $478 \mathrm{~F}$ Supp 1342 (Dist Mass 1979).

15. Gostin L, Curran WJ: Legal control measures for AIDS: Reporting requirements, surveillance, quarantine, and regulation of public meeting places. Am J Public Health 1987;77:214-218.

16. Bowers $v$ Hardwick, 196 S Ct 2841 (1986).

17. Whalen $v$ Roe, 429 US 589 (1977).

18. Gostin L: The future of communicable disease control: Toward a new concept in public health law. Milbank Q 1986;64(suppl 1):79-96.

19. Roden R: Educating through the law: The Los Angeles AIDS discrimination ordinance. UCLA Law Rev 1986;33:1410-1441.

20. School Board of Nassau County, Florida v Arline, $107 \mathrm{~S} \mathrm{Ct} 1123$ (1987). 